\title{
The Importance of Technopreneurship Management Model for Vocational School
}

\author{
Muhammad Harlanu, ${ }^{\mathrm{a}, 1}$, Agus Nugroho ${ }^{\mathrm{b}}$ \\ ${ }^{a}$ Department of Electrical Engineering Education, Engineering Faculty, Semarang State University \\ ${ }^{\mathrm{b}}$ Department of Mechanical Engineering Education, Engineering Faculty, Semarang State University \\ UNNES Sekaran, Gunungpati, Semarang, Central Java, INDONESIA \\ ${ }^{1}$ harlanute_unnes@yahoo.com
}

\begin{abstract}
The lack of Indonesian technopreneur opens great opportunity for vocational school graduates to become technopreneur instead of becoming an employee or a college student. It is due to their competence supported by three-yearentrepreneurship education at vocational school. This study is to find out the actual existing entrepreneurship education profile at vocational school and teachers' perception regarding the importance development of technopreneurship education model at school. Some governmental vocational schools in Semarang were investigated. This study worked on descriptive qualitative and quantitative methods. The stakeholders' perception regarding this model was discussed in this study. The finding describes the actual existing implemented entrepreneurship education management at vocation school and the stakeholders' perception toward technopreneurship model implementation. It shows that $83 \%$ stakeholders strongly agree and $17 \%$ agree that its soft-skill aspect should be added in the learning model.
\end{abstract}

Index Terms - vocational school, technopreneurship model, soft-skill

\section{Introduction}

One of the critical problems faced by Indonesia mostly deals with Indonesia's low competitiveness to other countries. The competitiveness is not only determined by the abundance of natural resources and cheap labors, but also by both excellence and innovation of science.

In firm perspective, empirical observation confirms that resources (such as capital, labor, technology) and talent tend to concentrate geographically. This result reflects the fact that firms are embedded in inter-firm relationships with networks of suppliers, buyers and even competitors that help them to gain competitive advantages in the sale of its products and services. While arms-length market relationships do provide these benefits, at times there are externalities that arise from linkages among firms in a geographic area or in a specific industry (textiles, leather goods, silicon chips) that cannot be captured or fostered by markets alone. The process of "clusterization" the creation of "value chains," or "industrial districts" are the models that highlight the advantages of networks [1]. However in national perspective, competitiveness could be defined as scholarly national competitiveness which has largely been qualitatively described systematically by academics. It is to define meaningfully and analyze national competitiveness which have been made; with the determinants of national competitiveness econometrically model [2]. The aims of this study was to investigate the entrepreneurship education management's portrait at vocational school recently and the stakeholders' perspective toward the technopreneurship education management implementation.

\section{Previous Study}

a. Entrepreneur

Promoting entrepreneurship has become common since the $1980 \mathrm{~s}$ and it keeps running recently. Entrepreneurship is about becoming a boss at our own, giving something back to the people, and be an active economy agent on everyday life. Governments around the world are constantly discussing new ways and methods to increase the number of entrepreneurs and obviously some regular basis articles like newspapers, magazines and other popular media also try to identify and challenge individuals to create firms and markets [3]. The effects of technological change on economic growth and development stimulate extensive research in multiple disciplines, including geography and planning, regional science, entrepreneurship, technology that involves economics policy [4]. The youth unemployment issue usually covers various policies related to it (including education and training), and active labor market policy [5] . The importance of technological entrepreneurship as a factor in the creation of both individual and regional wealth has recently generated considerable interest. The origins of this interest can, in some part, be traced to a unique pair (as found in U.S); first, the tremendous individual entrepreneurship that gives rise to the personal computer and internet industries; and second, the resultant economic growth that the success of these two industries brought to the communities in which they are locatedmost notably, Silicon Valley [6].

\section{b. Entrepreneur in Education}

In European community, entrepreneurship is an important European Union objective for education and lifelong learning policies. The entrepreneurship educations in higher and vocational education develop competencies for entrepreneurship, enterprising behavior and employability for vocational graduates [7]. Entrepreneurship has become a widely taught subject in universities and business schools, therefore graduates with an entrepreneurship major are more likely to start new businesses and have stronger entrepreneurial intentions than other graduates [8]. Many factors have influenced entrepreneurial thinking and attitudes towards entrepreneurship in vocational schools [9]. A critical evaluation of the literature on entrepreneurship education highlighted a number of inherent definitional, conceptual and contextual issues relating to this area of research. New research would offer a realistic and relevant benchmark to evaluate and inform progress in entrepreneurship 
education at local, regional and national levels [10]. The success of business incubators and technology in university settings is often determined by how well technology is transferred from the laboratories to their startup firms. University technology transfer offices (UTTOs) function as "technology intermediaries" in fulfilling this role. Yet, entrepreneurship theory and research on the role of the UTTO in business incubation and new company formation are sparse. The study reveals a complex set of relationships between UTTO structure and strategies, new company formation, and business incubation [11].

\section{Method}

This study worked on survey method to gather a number of data from the stakeholder in Semarang City, Central Java, Indonesia. The gathered data shown in pie diagram were analyzed qualitatively and quantitatively.

\section{Result and Discussion}

This study utilized survey method to gather a number of data from the stakeholder in Semarang City, Central Java, Indonesia has been conducted in this study. The gathered data shown in pie diagram, analyzed qualitatively and quantitatively.

a. Recent Entrepreneurship Education Management in

The Vocational School

Figure 1 shows the recent management that implements one-line management in delivering the subject with teacher centered based:

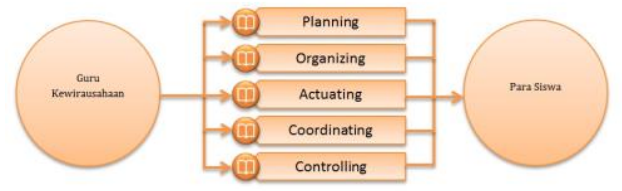

Fig1. Recent Education Management at Vocational School

\section{Teacher}

Through the recent model the teacher is the only knowledge source for students. Therefore the teacher's knowledge level would impact to the students' knowledge linearly. The study finds that the teacher only used entrepreneurship basic books and they did not improve the teaching and learning material from other books and online reference regarding the entrepreneurship. The teacher provided teaching material based on basic curriculum only with almost $90 \%+$ class lecturing without executing workshop or business project.

\section{Teacher Centered based Education}

The teaching and learning were run with traditional method. The teacher provided teaching material by giving speech to the students throughout the whole dedicated learning hour. Therefore students passively followed the course every single meeting instead of participating in the learning process actively. The students did not get enough stimuli from the teacher to stimulate their thought and ideas concerning the particular theme. It obviously affected the students' creativity when it came to both individual and group assignments.

\section{Management Function in Teaching}

During the teaching and learning process, the teachers had been implemented management function. They were (1) planning; the teacher prepared the entire year of their study materials, daily meeting planning and the evaluation, (2) organizing; the teacher organized teaching and learning in the class every single meeting, (3) actuating; the teacher executed the teaching and learning activities in the class individually, (4) coordinating; the teacher coordinated the teaching and learning activities with the vice head master of curriculum and (5) controlling; the teacher took full control to the students in the class during the learning process.

\section{Learning Process}

Learning process was done in the class only with $90 \%+$ theoretically through the teacher's speech only. The teachers did not involve any multimedia teaching aids to help the students in understanding the particular subjects due to lack of facilities. As the result, the daily learning process was away from dynamic learning process which should have involved students' participation during the learning process. This was one of the reasons why the students did not have motivation to follow the entrepreneurship education, moreover to become an entrepreneur or technopreneur once they graduated

\section{Assignment}

Students did not get any particular and relevant assignments to their education background. Consequently, the students did not have any idea to implement the entrepreneurship theory into a real practice. Therefore, the students thought entrepreneur education was not important since they did not get used to the actual entrepreneurship assignments moreover to the entrepreneurship-technology based assignments.

\section{b. Stakeholders' Perspective}

\section{Concept}

The concept of the technopreneurship education management for vocational school is an education management that stimulates students to implement entrepreneurship attitude in their daily life. As a matter of fact that the study was focused on engineering vocational school only so the ultimate outcome of this model is becoming a technopreneur once the students graduated from the school. A technopreneur means an entrepreneur who involves and deal with technology in their business. A technopreneur believes that technology would increase efficiency, productivity, product quality, broaden the market and helps to market the developed product widely. Therefore education management application also would deal with technology to boost the students' motivation in studying entrepreneurship subject before they implement its values in their daily life as young technopreneur

\section{The School Management Model Needs}

The following charts show the stakeholders' perspective regarding the technopreneurship education model idea: 


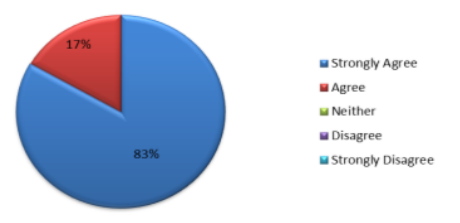

Fig 2. Soft Skill Aspect and Learning Model

Figure 2 shows there are $83 \%$ respondents strongly agree and $17 \%$ respondents agree on the idea that soft skill aspect must be added to the technopreneurship learning model.

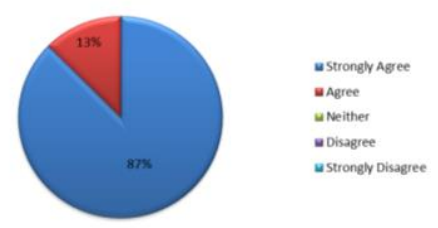

Fig 3. Soft Skill and Learning Process

Figure 3 shows there are $87 \%$ respondents strongly agree and $13 \%$ respondents agree on the idea that soft skill aspect must be implemented to the technopreneurship learning model in the class room during teaching and learning process.

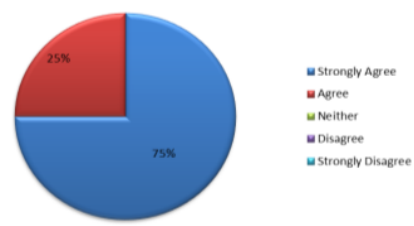

Fig 4. Linearity Technopreneurship Subjects with Students' Department

Figure 4 shows there are $75 \%$ respondents strongly agree and $25 \%$ respondents agree on the idea that technopreneurship subjects must be in-line with the students' department.

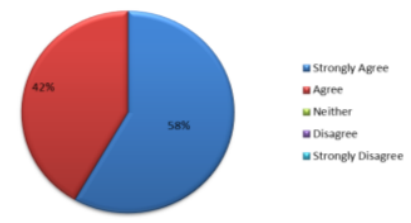

Fig 5. Soft Skill and Motivation

Figure 5 shows there are $58 \%$ respondents strongly agree and $42 \%$ respondents agree on the idea that soft skill

aspect in entrepreneur could boost students' motivation to become entrepreneur.

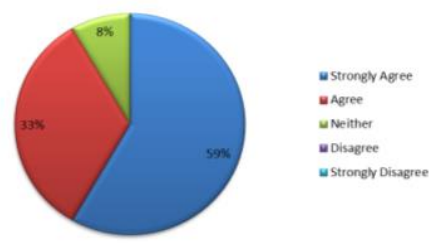

Fig 6. Soft Skill and Incubation

Figure 6 shows there are 59\% respondents strongly agree, $33 \%$ respondents agree and only $8 \%$ neither on the idea that studying entrepreneurship with soft skill aspect would be fun it is presented by a simulation or incubation model.

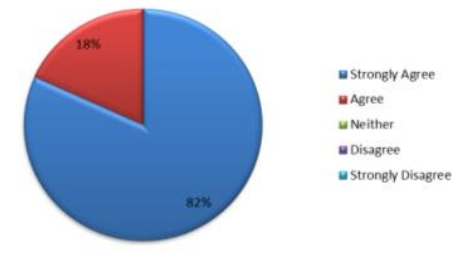

Fig 7. Composite Percentage 1

From the following indicators (1) teacher should provide enough chance to students to learn independently through provided handout, (2) students need to study independently in order to find out their internal new potency both knowledge and skill, and (3) it is important to invite successful business people in the class to share their experience to motivate students show that there are $82 \%$ respondent strongly agree and $18 \%$ respondent agree on the idea as shown above figure 7 .

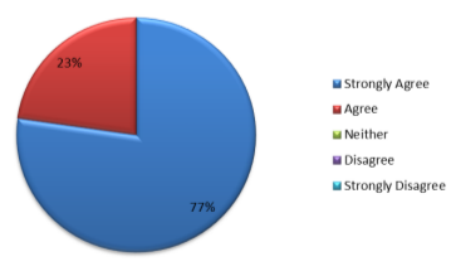

Fig 8. Composite Percentage 2

From the following indicators (1) teacher should help students in understanding provided handout concept, (2) teacher should assist students in solving the tasks, (3) it is important to ask feedback during the learning process, (4) project and simulation based learning are able to develop students' cooperative skill and students' cooperative skil is utilized in giving final score, there are $77 \%$ respondent strongly agree and $23 \%$ respondent agree on the idea as shown above figure 8 .

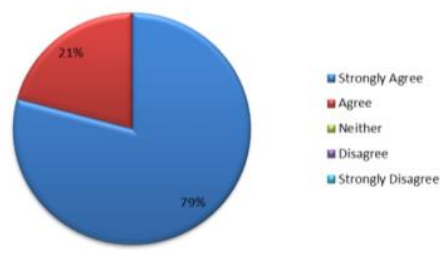

Fig 9. Composite Percentage 3

From the following indicators (1) the ability in solving problem is a kind of creative and critical thinking of the students and (2) in this model the teachers act as facilitator only, there are $79 \%$ respondent strongly agree and there were $21 \%$ agree on the idea as shown above figure 9 .

\section{Conclusion}

The study concluded that conventional entrepreneurship education model and its method are still being implemented at vocational school. This confirmed the students' preference not to follow the entrepreneurship education due to lack of motivation. The gathered data show that most of the respondents are at the level of 'strongly agree' and 'agree' on the idea of 
technopreneurship education management model's implementation at vocation school. However the future study is needed to find out the most suitable technopreneur education management model for the particular vocational schools.

\section{Acknowledgment}

The authors acknowledge the support by Research Institutions and Community Service of Semarang State University and Government Vocational Schools in Semarang, Central Java, Indonesia.

\section{References}

[1] Easterly, W., \& Levine, R. (2002). It's not factor accumulation: stylized facts and growth models

[2] Thompson, E. R. (2004). National competitiveness: a question of cost conditions or institutional circumstances?. British Journal of Management, 15(3), 197-218

[3] Becker, S. O., \& Hvide, H. K. (2013). Do entrepreneurs matter? (No. 7146). Discussion Paper Series, Forschungsinstitut zur Zukunft der Arbeit.

[4] Malecki, E. J. (1997). Technology and economic development: the dynamics of local, regional, and national change. University of Illinois at Urbana-Champaign's Academy for Entrepreneurial Leadership Historical Research Reference in Entrepreneurship

[5] O'Higgins, N. (2001). Youth unemployment and employment policy: A global perspective.

[6] Venkataraman, S. (2004). Regional transformation through technological entrepreneurship. Journal of Business venturing, 19(1), 153-167.

[7] Onstenk, J. (2003). Entrepreneurship and vocational education. European educational research journal, 2(1), 74-89.

[8] Kolvereid, L., \& Moen, Ø. (1997). Entrepreneurship among business graduates: does a major in entrepreneurship make a difference?. Journal of European industrial training, 21(4), 154160.

[9] Frank, H., Korunka, C., Lueger, M., \& Mugler, J. (2005). Entrepreneurial orientation and education in Austrian secondary schools: Status quo and recommendations. Journal of Small Business and Enterprise Development, 12(2), 259-273.

[10] Matlay, H. (2005). Entrepreneurship education in UK business schools: Conceptual, contextual and policy considerations. Journal of Small Business and Enterprise Development, 12(4), 627-643.

[11] Markman, G. D., Phan, P. H., Balkin, D. B., \& Gianiodis, P. T. (2005). Entrepreneurship and university-based technology transfer. Journal of Business Venturing, 20(2), 241-263. 